\title{
Corrigenda
}

Genome Research 30: 427-436 (2020)

\section{Corrigendum: Human auditory ossicles as an alternative optimal source of ancient DNA}

Kendra Sirak, Daniel Fernandes, Olivia Cheronet, Eadaoin Harney, Matthew Mah, Swapan Mallick, Nadin Rohland, Nicole Adamski, Nasreen Broomandkhoshbacht, Kimberly Callan, Francesca Candilio, Ann Marie Lawson, Kirsten Mandl, Jonas Oppenheimer, Kristin Stewardson, Fatma Zalzala, Alexandra Anders, Juraj Bartík, Alfredo Coppa, Tumen Dashtseveg, Sándor Évinger, Zdeněk Farkaš, Tamás Hajdu, Jamsranjav Bayarsaikhan, Lauren McIntyre, Vyacheslav Moiseyev, Mercedes Okumura, Ildikó Pap, Michael Pietrusewsky, Pál Raczky, Alena Šef̌ćáková, Andrei Soficaru, Tamás Szeniczey, Béla Miklós Szőke, Dennis Van Gerven, Sergey Vasilyev, Lynne Bell, David Reich, and Ron Pinhasi

The authors would like to correct the affiliation of coauthor Mercedes Okumura to the following:

Department of Genetics and Evolutionary Biology, Institute of Biosciences, University of São Paulo, Cidade Universitária 05508-090 São Paulo, Brazil

The correction has been made in the revised article online.

doi: $10.1101 /$ gr.266098.120

Genome Research 29: 1152-1163 (2019)

\section{Corrigendum: OMA standalone: orthology inference among public and custom genomes and} transcriptomes

Adrian M. Altenhoff, Jeremy Levy, Magdalena Zarowiecki, Bartłomiej Tomiczek, Alex Warwick Vesztrocy, Daniel A. Dalquen, Steven Müller, Maximilian J. Telford, Natasha M. Glover, David Dylus, and Christophe Dessimoz

The authors would like to correct the omission of additional Supplemental Data files, which were inadvertently excluded from the initial publication of this article. Please note that the complete Supplemental Data file has now been published online as Revised Supplemental Material. The authors apologize for the inconvenience.

doi: 10.1101/gr.266809.120 


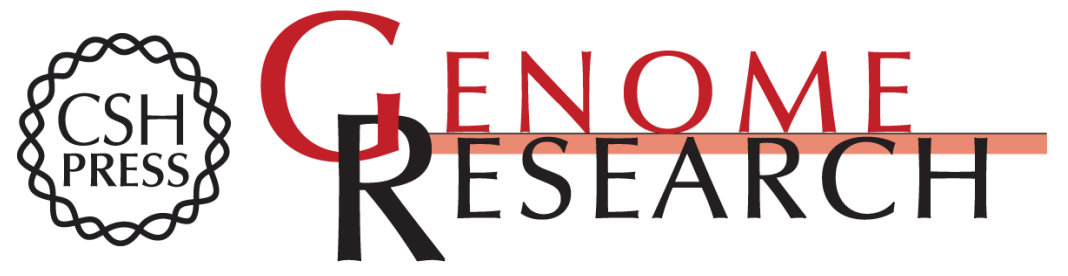

\section{Corrigendum: Human auditory ossicles as an alternative optimal source of ancient DNA}

Kendra Sirak, Daniel Fernandes, Olivia Cheronet, et al.

Genome Res. 2020 30: 938_1

Access the most recent version at doi:10.1101/gr.266098.120

\section{Related Content Human auditory ossicles as an alternative optimal source of ancient DNA}

Kendra Sirak, Daniel Fernandes, Olivia Cheronet, et al.

Genome Res. March , 2020 30: 427-436

Open Access Freely available online through the Genome Research Open Access option.

\section{License}
Email Alerting Receive free email alerts when new articles cite this article - sign up in the box at the Service top right corner of the article or click here.

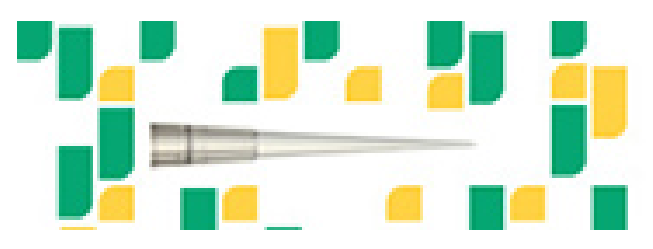

To subscribe to Genome Research go to: https://genome.cshlp.org/subscriptions 